\title{
Pemindahan Ibu Kota Negara Maju dan Sejahtera
}

\author{
H. M Yahya ${ }^{\mathrm{a}, 1}$ \\ ${ }^{a}$ Universitas Merdeka Malang, Jawa Timur, Indonesia \\ ${ }^{1}$ h.myahya25@gmail.com
}

Article history:

Received : 2018-02-06

Revised : 2018-06-29

Accepted : 2018-06-30

Keywords:

Displacement of capital city

Prosperous

Central Kalimantan Province Discourse

The discourse to move the Indonesian capital city has repeatedly emerged. It occurs when critical events arise from social, political, environmental and disaster factors. The purpose of this study is to analyze how the discourse of Central Kalimantan as the Indonesian capital city. The method of this research uses qualitative approach with library research analysis. It uses primary books on public feasibility of an area becoming capital city of Indonesia. The results of this study with spatial, ecological and territorial approach, where Jakarta as a consideration for discussion. So in the temporary hypothesis, Jakarta is less feasible as the capital city of the country. Meanwhile, Central Kalimantan becomes alternative city to be the capital city. It is representative of its vast territory, not vulnerable to natural disasters, added a small population of its citizen.

Copyright (C) 2018 IAIN Palangka Raya. All rights reserved.

\section{Pendahuluan}

Semenjak Negara Kesatuan Republik Indonesia (NKRI) memproklamirkan kemerdekaannya pada tanggal 17 Agustus 1945, belum pernah ada wacana untuk membangun kota sebagai ibu kota negara atau ibu kota nasional. Kota-kota besar yang saat ini menjadi ibu kota negara (Jakarta) dan ibu kota provinsi semuanya atau sebagian besarnya merupakan peninggalan kolonialisme Belanda. Jauh berbeda dengan zaman kejayaan kerajaan di nusantara dahulu, sebelum mengalami penjajahan, hampir semua mempunyai dan membangun ibu kota (kota raja). Sebagai contoh Majapahit memiliki peninggalan situs Trowulan yang dianggap sebagai pusat pemerintahannya; Mataram dengan Yogyakarta sebagai pusat pemerintahannya. Perpindahan pusat pemerintahan sering terjadi di zaman kerajaan. Apabila suatu kerajaan tertimpa bencana, maka pusat kerajaan harus dipindahkan karena di anggap telah terkena kutukan dewa. Pergantian rajapun dilakukan seiring dengan perpindahan pusat

pemerintahan, apalagi jika pergantian tersebut melalui perebutan.(7)

Sebagaimana halnya dengan NKRI, tampaknya para pemimpin NKRI pada awal DOI: $10.23971 /$ jsam.v14i1. kemerdekaan memiliki filsafat: tidak ada rotan akarpun jadi dan narimo. Dalam arti bahwa daripada membangun ibu kota baru dan istana negara baru, yang sudah ada sajalah dimanfaatkan, yakni memanfaatkan bekas kantor gubernur penjajah sebagai istana kenegaraan. Kondisi tersebut dianggap wajar dan dapat dimaklumi karena negara yang baru merdeka dan terjajah selama lebih dari 3 abad belum mempunyai kemampuan untuk membangun.

Peristiwa pemindahan ibu kota negara telah banyak dilakukan oleh beberapa negara, dengan alasan yang beragam. Contoh berikut ini memberikan gambaran bahwa pemindahan ibu kota negara merupakan peristiwa yang tidak tabu dan dilaksanakan dengan tujuan memecahkan permasalahan demi kebaikan maupun kemajuan bangsa dan negara. Sebagai salah satu contohnya, pertama, Brasilia ibu kotanya terletak di pedalaman, karena ibu kota lama Rio Jenairo sudah terlalu padat. Kedua, pemerintah Korea Selatan pada tahun 2004 ibu kotanya pindah dari Seoul ke Sejong, meskipun Seoul itu berarti ibu kota dalam bahasa Korea. Ketiga, ibu kota tradisional yang secara ekonomi memudar akibat kota pesaingnya, seperti Nanjing yang memudar oleh Shanghai. Keempat, akibat menurunnya suatu dinasti atau budaya, akhirnya ibu kota yang ada 
menjadi pudar dan kalah pamor seperti yang terjadi di Babilon dan Cahokia.(5)

Pemindahan ibu kota di NKRI sangat dimungkinkan karena di dalam UndangUndang Dasar Republik Indonesia dan Amandemennya tidak diatur secara tegas. Dalam Bab II ayat (2) UUD NKRI tertulis: Majelis Permusyawaratan Rakyat bersidang sedikitnya sekali dalam lima tahun di ibu kota negara. Dalam UUD tersebut tidak ada pasal yang menyebutkan dimana dan bagaimana ibu kota negara diatur. Dengan demikian terdapat fleksibilitas yang tinggi dalam mengatur termasuk memindah ibu kota negara. Dalam pemindahan ibu kota negara, tentu saja diperlukan alasan yang kuat dan mendasar tentang efektifitas fungsinya.

Ada wacana alternatif pertama pemindahan dan pergiliran ibu kota, bahwa kondisi Jakarta sebagai ibu kota negara yang terlalu lama sampai saat ini sangat tidak ideal buat pemerataan pembangunan nasional. Seperti halnya hukum besi kekuasaan yang absolut di tangan satu orang, tanpa pergiliran. Kalau kita perhatikan semuanya ada di Jakarta, mulai dari ibu kota negara, kantorkantor pemerintahan, kantor-kantor pusat BUMN, pusat perdagangan, konsentrasi populasi, pusat perindustrian dan lain-lain. Kondisi ini tentu tidak ideal, fungsi yang satu seringkali menghambat fungsi yang lain yaitu keadilan sosial bagi seluruh rakyat Indonesia. Idealnya, beberapa fungsi tersebut perlu dipindahkan ke kota lain. Memindahkan aktivitas perekonomian akan sangat sulit, tapi bukan tidak mungkin fungsi sebagai ibu kota dipindahkan ke kota lain demi memperbesar daya dukung kota lama untuk nyaman dihuni dan memberi kesempatan kota baru dan kawasannya juga ikut berkembang.

Ada alternatif kedua, ibu kota negara tetap di Jakarta dengan pemindahan beberapa departemen dan pusat-pusat kegiatan ekonomi dan pembangunan ke luar Jakarta, dengan tujuan mengurangi beban Jakarta. Alternatif ini tampaknya lebih banyak menghadapi kesulitan dibandingkan dengan alternatif pertama. Beban Jakarta memang berkurang, tetapi tidak berarti sudah meniadakan permasalahan karena banjir tetaplah menjadi ancaman. Apalagi jika pemindahan pusat kegiatan diarahkan ke selatan Jakarta. Banjir akan semakin meningkat bila tidak diikuti dengan usaha konservasi lahan di bagian atas. Melalui "momentum" banjir di Jakarta pada awal Februari 2007 dan masih terasa efeknya hingga kini, ada baiknya kita merenung dan berpikir. "Bagaimana seandainya ibu kota negara Indonesia benar-benar dipindah saja?" Sebagai ibu kota, Jakarta terbukti kelebihan beban dan cenderung sudah kurang layak lagi menjadi kota lokomotif bagi bangsa nusantara ini.

Ada pro dan kontra seputar kejadian banjir di Jakarta, sebagai alasan pemindahan ibu kota. Alasannya, banjir tidak meliputi seluruh wilayahnya, masih ada sebagian yang tidak terkena. Bagi penduduk yang tinggal di daerah yang tidak terkena banjir tentunya tidak sependapat apabila ibu kota negara dipindahkan, dan menghendaki tetap dipertahankan. Apabila dasar pemikirannya sempit dan jangka pendek maka alternatif ke dua yang dipilih. Namun dalam pemikiran yang lebih luas dan jangka panjang bahwa Indonesia dengan potensi sumberdaya alamnya yang melimpah dan sumberdaya manusia yang cukup besar akan menjadi negara yang besar dan kuat, maka alternatif pemindahan ibu kota ke dua menjadi lemah.

Sebelum menentukan alternatif untuk menentukan pilihan lokasi pemindahan ibu kota negara, terlebih dahulu perlu dicari rumusan ibu kota negara yang ideal. Penelusuran pustaka tentang syarat ibu kota negara yang ideal cenderung belum optimal ditemukan. Berdasarkan pemikiran geografis ibu kota negara yang ideal harus mempertimbangkan aspek spasial, ekologis, dan kewilayahan; maka perlu antara lain adalah: tersedia lahan yang sesuai, aman, nyaman, lingkungan sehat, bebas dari bahaya dan bencana, aksesibilitas dan arus informasi memadai, ketersediaan lahan untuk perwakilan negara sahabat (kedutaan), ketersediaan air bersih, fasilitas umum, fasilitas kesehatan, masyarakat sekitar kondusif dan tidak menimbulkan ketimpangan antara wilayah. Berdasarkan rumusan tersebut kemudian dikaitkan dengan kondisi geografis Indonesia untuk menentukan alternatif lokasi sebagai calon ibu kota negara.

Beberapa pandangan tentang alternatif pemindahan ibu kota negara yang munncul 
pada periode Mei 1998 (gerakan reformasi) adalah Yogyakarta, Magelang, Purwokerto, Malang, dan Kalimntan Tengah.(3) Beberapa alternatif lokasi tersebut mempunyai keunggulan dan kelemahan. Yogyakarta memiliki keunggulan pernah menjadi ibu kota negara dan berfungsi dengan baik. Fasilitas transportasi sudah tersedia, yaitu Bandara Adi Sutjipto dan Stasiun Kereta Api Tugu. Yogyakarta dikenal sebagai kota pelajar, dan kota budaya; sehingga berpendudukan padat dan jalanan sempit menyebabkan kurang memungkinkan untuk ditambahi beban, kecuali dengan pembenahan aksesibilitas, pemilihan lokasi yang tepat, dan tidak menempati lokasi bangunan peninggalan Belanda.

Alternatif lain, jika Magelang, pertimbangannya letaknya di tengah pulau Jawa, sering dikenal dengan pakuning tanah Jawa berarti daerahnya mantap. Namun demikian, lokasinya berdekatan dengan Gunungapi Merapi yang masih aktif, sehingga bahaya vulkanik merupakan ancaman. Aksesibilitas dapat didukung dari Yogyakarta dan Semarang. Purwokerto mempunyai kelebihan ketersediaan ruang (lahan) yang masih dimungkinkan untuk pembangunan ibu kota. Aksesibilitas laut dapat terdukung dari pelabuhan Cilacap, sedangkan akses darat dapat dicapai dari Yogyakarta dan Bandung. Transportasi udara perlu dibangun. Gunungapi Slamet mungkin merupakan bahaya, tetapi berdasarkan sejarahnya kurang aktif. Selain itu, terdapat Baturaden sebagai tempat peristirahatan yang layak. Malang mempunyai lingkungan pegunungan yang sejuk, didukung oleh aksesibilitas darat dan udara yang memadai, dan dekat dengan Surabaya. Namun demikian, Malang termasuk kota pelajar dan padat penduduk, jalan di dalam kota umumnya sempit.(3)

Alternatif pemindahan ibukota negara ke luar Jawa, pilihannya adalah Kalimantan Palangkaraya, jika dijadikan Ibukota negara, maka diperkirakan bisa bertahan hingga 200300 tahun ke depan. Hal ini disebabkan masih banyak lahan kosong disana dan Sumatera Bikuttinggi alasannya karena sejuk dan bersejarah, Batam perbatasan dengan Singapura, agar kemakmurannya menular ke ibukota baru, sudah ada sekitar 6 jembatan antar pulau sekitarnya. Kelebihan dari
Kalimantan adalah lokasinya merupakan pusat dari wilayah Nusantara. Lahan masih sangat luas, sehingga dapat menyusun tata ruang ibukota negara yang sangat ideal. Kelemahannya adalah sarana dan prasarana belum memadai, sebagian besar harus membangun yang baru, berarti biaya mahal. Kelemahan lainnya adalah penyediaan air bersih, kebakaran hutan, banjir dan longsor merupakan bahaya yang perlu dijadikan dasar pertimbangan. Sumatera merupakan alternatif lain, ketersediaan lahan memadai, sebelah barat Bukit Barisan rawan terhadap bencana gempa, sehingga daerah yang sesuai tentunya di sebelah timur Bukit Barisan.(8)

Wilayah bumi cendrawasih pun bisa dijadikan wacana sebagai ibukota negara kita. Jika mempertimbangkan luas dan lapangnya lahan sebagai lokasi. Begitu pula kemungkinan Sulawesi Utara, NTT dan NTB untuk menjadi ibukota, atau semuanya akan mendapat giliran secara berkala. Presiden SBY mempersilakan wacana pemindahan ibukota dari Jakarta. Menurut SBY, dalam berdemokrasi setiap orang bebas berpendapat.

Pemindahan ibukota seharusnya menjadi studi yang sudah dilakukan Bappenas. Menteri Pekerjaan Umum kabinet SBY, Djoko Kirmanto pernah mengatakan, rencana pemindahan itu mungkin dilaksanakan, selama pembahasannya dilakukan secara cermat berupa hitung-hitungan ekonomi, dan sektor lain, seperti manfaat jangka panjang proyek membangun keindonesiaan yang lebih adil dan maju bersama. Ada pula pandangan ketua AIPI Ryaas Rasyid bahwa ibukota negara RI harus dipindahkan dari Jakarta selambat-lambatnya 10 tahun lagi atau tahun 2016. Sebab, saat ini Jakarta sudah sangat padat sehingga sudah tidak layak lagi menjadi ibukota negara.

Berdasarkan hal itu, negara dan masyarakat hendaknya segera menyusun konsep strategis kebijakan publik menyangkut politik perkotaan di Indonesia mulai sekarang. Kalau pemerintah berpikiran cerdas dan mau sungguh-sungguh demi kebaikan dan kesejahteraan untuk masa depan, maka perlu mengkaji dan merancang model pemindahan ibu kota dari sekarang.

Selain ibukota negara dipindahkan terdapat juga pemindahan sebagian dari kekuasaan pemerintah, contoh berikut dapat 
dijadikan salah satu alternatif untuk pemecahan masalah yang terkait dengan ibu kota negara. Beberapa contoh pemindahan kota negara seperti: Bolivia: Succre masih ibu kota konstitusional tetapi pemerintahan nasional telah lama ditinggalkan dan beralih ke La Paz. Kemudian Chili: Santiago masih dianggap sebagai ibu kota meskipun Kongres Nasionalnya di Valparaiso, juga Belanda: Amsterdam ibu kota nasional konsitusional, meskipun pemerintahan Belanda, parlemen, istana ratu semuanya terletak di Den Haag, dan Afrika Selatan: ibu kota administratif di Pretoria, ibu kota legislatifnya di Cape Town dan ibu kota judisialnya di Bloemfontein.

Pemindahan sebagian kekuasaan pemerintah di NKRI sangat dimungkinkan, karena di dalam Undang-Undang Dasar Republik Indonesia dan Amandemennya tidak diatur secara tegas. Dalam Bab II ayat (2) UUD NKRI tertulis: Majelis Permusyawaratan Rakyat bersidang sedikitnya sekali dalam lima tahun di ibu kota negara. Dalam UUD tersebut tidak ada pasal yang menyebutkan dimana dan bagaimana ibu kota negara diatur. Dengan demikian terdapat fleksibilitas yang tinggi dalam mengatur, termasuk memindah ibu kota negara. Pemindahan ibu kota negara tentunya perlu ada alasan yang kuat dan mendasar tentang efektifitas fungsinya.

Banyak kalangan berpendapat bahwa jika ibu kota negara dipindahkan dari Jakarta, maka negara Indonesia akan menjadi negara serikat seperti Singapura. Jika ibu kota dipindahkan, permasalahan yang akan muncul terkait permasalahan infrastruktur dan bagaimana jenis pengaturan nantinya, termasuk apabila pemindahan ibu kota dilakukan maka akan terjadi perubahan tatanan yang luar biasa. Beberapa presiden seperti Soekarno pernah menginginkan ibu kota baru kemudian selanjutnya Susilo Bambang Yudhoyono dan Joko Widodo, namun hingga saat ini tidak pernah terlaksana.(10)

\section{Kajian Pustaka}

\section{Gambaran Umum Provinsi Kalimantan Tengah}

Provinsi Kalimantan Tengah yang mempunyai luas wilayah $153.564 \mathrm{~km}^{2}$ atau
1,5 kali luas pulau Jawa berdiri sebagai provinsi Indonesia ke 17, setelah berpisah dengan induknya Kalimantan Selatan, berdasarkan Keppres No.10/1957 tanggal 23 Mei 1957. Latar belakang berdirinya adalah sebagai wujud apresiasi rezim Soekarno terhadap peran serta masyarakat Dayak yang mayoritas non-Muslim dalam pembangunan. Sebelumnya, Kalimantan Tengah diperjuangkan lewat diplomasi oleh Alm Tjilik Riwut dan kawan-kawan, dan perjuangan berdarah-darah, lewat pemberontakan bersenjata Gerakan Mandau Talawang Pancasila (GMTPS) yg dipimpin oleh Alm. Cristian Simbar. Saat ini Kalimantan Tengah terdiri dari 13 kabupaten dan 1 Kota Madya.(9) Komposisi penduduknya yaitu Dayak (Ngaju, Dohoi, Dusun, Maanyan, Lawangan, Bakumpai, dan lain-lain) $36 \%$, Banjar 24\%, Jawa 18\%, selebihnya Cina, Arab, Bugis, Batak, dan lain-lain sebanyak 22\%. Dilihat dari komposisi agama yang dipeluk, warga yang beragama Islam sebanyak 69,67\%, Protestan $16,41 \%$, Katolik 3,11\%, Hindu/Kaharingan $10,69 \%$ dan penganut Buddha 0,12\%.

Masyarakat asli Kalimantan Tengah, yaitu "Uluh Dayak" umumnya berpencaharian sebagai petani/nelayan tradisional. Biasanya, orang Dayak tidak berprofesi tunggal. Misalnya; pekerjaan tetapnya menyadap karet, selain itu juga mengurusi kebun. Dimusim ikan, mereka bisa menjadi nelayan juga. Sebagian penduduk Kahayan bagian tengah sampai hulu, Kapuas hulu dan Barito hulu juga berprofesi ganda sebagai penambang emas juga. Para transmigran yang berasal dari Jawa, NTT, dan Bali berprofesi sebagai petani. Para petani diwilayah Kapuas bagian Timur umumnya adalah orang-orang Banjar. Diseantero Kalimantan Tengah, orang Banjar dikenal sebagai pebisnis atau pedagang yang ulet dan tangguh. Pasar- pasar umumnya "dikuasai" oleh orang Banjar. Orang Bakumpai yang sebagian besar tinggal di DAS Barito umumnya adalah petani karet, rotan dan nelayan. Demikian pula orang Dusun, Maanyan, Lawangan, dan sub suku Dayak Ngaju lainnya.

Kepercayaan asli Dayak yaitu Kaharingan masih tetap kukuh dianut oleh sebagian masyarakat Dayak, terutama yang berdiam di wilayah Kab.Gunung Mas, Katingan, sebagian kecil di DAS Barito dan pedalaman 
Kotawaringin Timur (Kotim) dan Kotawaringin Barat (Kobar). Masyarakat Dayak Kalimantan Tengah adalah masyarakat yang egaliter, terbuka dan toleran terhadap pengaruh budaya asing. Kalau kita berkunjung hingga jauh kewilayah pedalaman, tidak ada perbedaan berarti antara orang Dayak dengan etnis lain di Indonesia. Perbedaan utama yang bisa kita jumpai hanyalah perbedaan bahasa saja. Salah satu keistimewaan Kalimantan Tengah adalah, meski sampai kepedalaman, kita tetap bisa berkomunikasi dengan mereka dengan Bahasa Indonesia.(9)

\section{Arti dan Fungsi Suatu Ibukota Negara}

Ibu kota (a capital; capital city; political capital) merupakan sebuah kota yang dirancang sebagai pusat pemerintahan suatu negara; secara fisik ibu kota negara umumnya difungsikan sebagai pusat perkantoran dan tempat berkumpul para pimpinan pemerintahan. Berasal dari bahasa Latin caput yang berarti kepala (head) kemudian dikaitkan dengan kata capitol yang berarti letak bangunan pusat pemerintahan utama dilakukan. Sejarahnya, ibu kota terbentuk melalui suatu penaklukan atau penggabungan. Ibu kota sebagai pusat perekonomian utama dari suatu wilayah juga senantiasa dijadikan titik pusat dari kekuatan politik, sehingga mempunyai daya tarik tersendiri yang diperlukan untuk efisiensi administrasi pemerintahan seperti ahli hukum, jurnalis dan peneliti kebijakan publik. Ibu kota merupakan pusat ekonomi, budaya atau intelektual.

Ibu kota telah menjadi simbol pemerintahan dan kenegaraan, serta menjadi tempat berkembangnya muatan politik, perekonomian dan budaya. Di kota-kota abad pertengahan, pemilihan dan pendirian suatu ibu kota modern terbentuk atas landasan emosional. Contoh-contohnya adalah sebagai berikut:(4)

1. Athena yang mengalami kehancuran dan hampir tak berpenduduk dijadikan ibu kota baru bagi Greece, sebagai simbol kejayaan masa lalu. Hal yang sama terjadi pada saat Perang Dingin dan Reunifikasi Jerman, dimana Berlin menjadi ibu kota lagi bagi Jerman.

2. Rusia memindahkan pemerintahannya dari Mosko ke Sain Petersburg untuk memberikan kebesaran Rusia beorentasi ke barat, hal tersebut merupakan suatu relokasi simbolik dari ibu kota ke lokasi geografis dan demografis dengan alasan ekonomi atau strategi (sering disebut ibu kota masa depan atau ibu kota pelopor).

3. Kemal Atarturk memindahkan pusat pemerintahan dari Ottoman Istambul ke Ankara.

4. Kaisar Ming memindahkan ibu kota dari Nanjing ke Beijing untuk menjauhi Mongols dan Manchus.

Ibu kota mempunyai fungsi yang penting, ibu kota senantiasa dijadikan sebagai target utama dalam peperangan, sebab dengan menguasai ibu kota akan menjadi jaminan untuk bisa menguasai sebagian besar musuh atau penentang, sehingga dapat menurunkan moral untuk mengalahkan musuh (militer). Seperti yang terjadi pasa masa lalu di China, dimana pemerintahannya sedikit terpusat pada fleksibilitas di tingkat provinsi, dengan ambruknya ibu kota dapat mengakibatkan runtuhnya suatu Dinasti. Oleh sebab itu Dinasti Ming memindahkan Ibu kota Nanjing ke Beijing dengan alasan agar dapat mengontrol musuh yang berasal dari Mongols dan Manchus.

Berkaitan dengan fungsi ibu kota negara yang penting, terdapat pandangan lain bahwa fungsi ibu kota negara kurang penting sebagai sasaran militer. Karena pusat pemerintahan dapat dipindahkan ke tempat lain. Sebagai contoh dalam perang revolusi dan perang tahun 1812 tentara Inggris berulangkali menyerang beberapa ibu kota Amerika, tentara Amerika tetap dapat bertempur dari luar kota, dimana mereka didukung oleh pemerintah setempat dan penduduk civil di perbatasan. Perkecualiannya adalah Perancis, yang birokrasinya terkordinasi dan terpusat secara efektif serta terdukung oleh sumberdaya yang sangat luas, menjadikan negaranya sangat kuat melebihi pesaingnya, akan tetapi dalam strategi militernya memiliki resiko tinggi apabila ibu kota diduduki oleh musuh. Ancaman tradisional dari Perancis adalah Jerman terfokus untuk menguasai Paris. Hal serupa juga terjadi di Indonesia, ketika Jakarta jatuh oleh tentara Belanda sewaktu perang revolusi ibu kota negara pernah berpindah ke Yogyakarta dan ke Bukit Tinggi. Dengan demikian pemerintahan tetap berjalan, sehingga NKRI tetap berdiri dengan 
melakukan perang gerilya untuk mempertahankan kemerdekaan.(6)

\section{Kondisi Jakarta Sebagai Ibu Kota}

Dalam sejarah, asal mula kota Jakarta berawal dari pekan pelabuhan kecil yang dikenal sebagai Sunda Kelapa, kemudian dikenal menjadi Kota Batavia. Seorang pengembara Inggris terkenal yaitu Kapten James Cook menyebutkan pelabuhan tersebut merupakan kawasan labuhan kapal besar dan kecil terbaik di dunia saat itu. Kota yang telah berumur hampir 500 tahun tersebut secara bertahap telah mengalami banyak perkembangan yang positif, namun sering kali terlanda banjir. Menurut catatan sejarah, akibat meluapnya Sungai Ciliwung pada tahun 1872 mengakibatkan jebolnya pintu air sehingga merendam kawasan Batavia. Peristiwa yang sama pernah terjadi pada 9 Januari 1932, akibat hujan yang turun deras sepanjang malam menyebabkan hampir seluruh wilayah kota Batavia terendam banjir. Salah satu upaya penanggulangan banjir Jakarta sebenarnya telah direncanakan sejak masa pemerintahan Belanda tahun 1920 oleh seorang insiyur Belanda bernama Van Breen yang saat itu memimpin pembangunan sejumlah pintu air dan saluran (banjir kanal), untuk mengakomodasi datangnya air.

Masalah banjir Jakarta memang sulit diatasi tanpa ada suatu usaha menyeluruh dan terpadu. Amblesan tanah akibat penurapan airtanah yang berlebih menjadi salah satu penyebab daerah menjadi sasaran banjir. Secara alami Jakarta memang rawan terhadap banjir, karena terletak pada kipas aluvial yang berkembang dari Selatan (Bogor) dan dialiri oleh 13 sungai dengan daerah hulunya bercurah hujan tinggi, yang sebagian lahannya telah terbangun. Faktor alami lainnya adalah di bagian Utara terdapat beting gisik (beach ridges) yang dapat menghambat aliran ke laut Teluk Jakarta. Sebenarnya pada beting gisik itupun terdapat cekungan antar beting yang dapat berfungsi sebagai penampung air, namun itupun sudah terbangun. Demikian juga sebagian besar situ-situ yang berfungsi sebagai penampung dan pengendali air hujan lokal itupun sudah menjadi lahan permukiman.

Hampir setiap tahun terjadi banjir yang besarnya bervariasi. Banjir yang terjadi tahun 2007 merupakan yang terbesar, hampir mencakup $70 \%$ wilayah Jakarta. Akibat banjir 2007 tersebut menimbulkan pemikiran atau gagasan untuk memindahkan Ibu Kota Jakarta. Banjir dijadikan salah satu pemicu ide untuk memindahkan ibu kota. Gagasan untuk memindahkan ibu kota negara telah mengemuka dalam berbagai kesempatan antara lain tanggal 20 Mei 1988 ketika gerakan reformasi. Waktu itu kondisi Jakarta sangat mengkhawatirkan sehingga muncul gagasan spontan, agar Yogya untuk menerima kembali fungsi ibu kota pemerintahan. Pemikiran untuk memindahkan ibu kota Negara juga datang dari Ketua DPR Agung Laksono dengan argumentasi sedikit berbeda, dan menyatakan bahwa Jakarta sudah saatnya kantor presiden yang menjadi pusat pengendali pemerintahan dipindahkan ke tempat yang lebih kondusif. Jakarta saat ini dinilai sudah kelebihan beban, baik secara ekonomi maupun sosial, sehingga Jakarta mempunyai multi fungsi. Ibu kota negara yang mempunyai multi fungsi umumnya akan menimbulkan berbagai dampak.(2)

\section{Dampak Multi Fungsi dari Jakarta}

Multi fungsi Jakarta merupakan dampak dari sistem pemerintahan sentralistis dan sistem multi fungsi yang memusat di Jakarta. Akibatnya sejumlah dampak sosial, politik, ekonomi dan ekologi menjadi beban Jakarta, berikut dampak yang dimaksud.(3)

1. Pemerintahan sentralitis yang dikendalikan secara otoriter dan serba seragam telah mengabaikan kemajemukan sosial budaya masyarakat dan keseragaman ekosistem wilayah negara kepulauan. Sistem kekuasaan yang memusat, membuat sistem pemerintahan daerah kehilangan kemandirian dan fungsi birokrasi tidak dapat berkembang melayani dan memfasilitasi partisipasi 
masyarakat, tetapi lebih melayani atasan atau pimpinan elitenya.

2. Kedekatan sumber pusat pemerintahan dan pusat ekonomi yang mengerucut pada elite dan hampir tanpa kontrol dari rakyat secara konstitusional maupun publik menyebabkan mewabahnya korupsi, kolusi dan nepotisme.

3. Pemusatan fungsi tersebut akhirnya membawa beban bagi Jakarta yang ditandai dengan ledakan jumlah penduduk, kemacetan lalu lintas, kesenjangan ekonomi, kerawanan sosial, kekerasan dan kejahatan.

4. Permasalahan tersebut diikuti krisis ekologi, yang berupa pencemaran udara, pencemaran air tanah, air bersih, banjir rutin, tata ruang yang semrawut, munculnya kawasan kumuh, lingkungan hidup yang kurang nyaman.

5. Konflik mudah terjadi antara kepentingan ekonomi dan ekologi, kepentingan sesaat dan jangka panjang, kepentingan elit dan masyarakat. Berdasarkan kondisi Jakarta dan berbagai dampak tersebut perlu dipertanyakan masih layakkah Jakarta sebagai ibu kota negara, dan apakah pemindahan ibu kota sebagai suatu keharusan atau sekedar wacana.

\section{Metodologi Penelitian}

Kajian ini meggunakan pendekatan analisis library research, dimana untuk menganalisis tentang perubahan ibu kota negara, perlu adanya referensi yang terkait baik berupa updating baik koran, majalah atau yang lainnya. Adapun referensi utama (data primer dari beberapa buku yang terkait dengan pemindahan ibu kota negara sebagai solusi pembangunan merata dan kesejahteraan.

\section{Hasil dan Pembahasan}

Orang Analisis garis besar aspek keruangan, ekologis dan kewilayahan serta dampak sosial, ekonomi, dan politik, menghasilkan suatu pemikiran bahwa: (i) pemindahan ibu kota merupakan suatu keharusan, tetapi dengan tenggang waktu, dan seharusnya tidak sebagai wacana lagi; (ii) ibu kota negara tetap di Jakarta tetapi pemindahan beberapa departemen dan pusatpusat kegiatan dialihkan ke luar Jakarta. Argumentasi dari masing-masing pemikiran adalah sebagai berikut.

Secara keruangan Jakarta sudah terlalu padat penduduk, sebagai pusat pemerintahan, perdagangan, perindustrian, pariwisata dan tata ruangnya semrawut, pemanfaatan lahan yang saling kontradiktif banyak terjadi. Pembangunan fisik terus dipacu tanpa arah yang jelas. Rencana Umum Tata Ruang (RUTR) yang sedemikan bagus disusun Bang Ali, (1966-1977), dengan mudahnya dapat berubah sehingga banyak peruntukan kota yang dilanggar. Banyak situ-situ yang berfungsi sebagai penampung air hilang menjadi perumahan. Program proyek kali bersih (prokasih) macet total. Tiga belas kali yang membelah kota ini tetap menjadi kubangan sampah. Rencana Induk 1965-1985 tidak berkelanjutan pada Rencana Induk 1985-2005, sangat dimungkinkan banyak campur tangan pihak pengusaha, terutama developer dengan para pejabat Pemda Jakarta.(11)

Jajak pendapat terhadap karyasiswa Program S2 Geografi menghasilkan pandangan bahwa ibu kota negara perlu dipindahkan. Banyak alternatif yang disampaikan meskipun belum disertai dengan argumentasi yang matang. Daerah yang diusulkan untuk dipilih pemindahan ibu kota negara adalah: tetap di pulau Jawa di luar Jakarta, Kalimantan, dan Sumatra. Sebelum menentukan alternatif untuk menentukan pilihan lokasi pemindahan ibu kota negara, terlebih dahulu perlu dicari rumusan ibu kota negara yang ideal. Penelusuran pustaka tentang syarat ibu kota negara yang ideal belum ditemukan; berdasarkan pemikiran geografis ibu kota negara yang ideal harus mempertimbangkan aspek spasial, ekologis dan kewilayahan antara lain adalah: tersedia lahan yang sesuai, aman, nyaman, lingkungan sehat, bebas dari bahaya dan bencana, aksesibilitas dan arus informasi memadai, ketersediaan lahan untuk perwakilan negara sahabat (kedutaan), ketersediaan air bersih, fasilitas umum, fasilitas kesehatan, masyarakat sekitar kondusif dan tidak menimbulkan ketimpangan antara wilayah. Berdasarkan rumusan tersebut kemudian 
dikaitkan dengan kondisi geografis Indonesia untuk menentukan alternative lokasi sebagai calon ibu kota negara.

Alternatif pemindahan ibu kota negara ke luar Jawa, pilihannya adalah Kalimantan dan Sumatra. Kelebihan dari Kalimantan adalah lokasinya merupakan pusat dari wilayah Nusantara. Lahan masih sangat luas, sehingga dapat menyusun tata ruang ibu kota Negara yang sangat ideal. Kelemahannya adalah prasarana dan sarana belum memadai, sebagian besar harus membangun yang baru, berarti biaya mahal. Kelemahan lainnya adalah penyediaan air bersih; kebakaran hutan, banjir dan longsor merupakan bahaya yang perlu dijadikan dasar pertimbangan. Sumatra merupakan alternatif lain, ketersediaan lahan memadai; sebelah barat Bukit Barisan rawan terhadap bencana gempa, sehingga daerah yang sesuai tentunya di sebelah timur Bukit Barisan. Alternatif pemindahan lokasi ibu kota negara tersebut di atas, baik yang tetap di pulau Jawa maupun di luar pulau Jawa merupakan awal dari pemikiran yang masih perlu didiskusikan secara mendalam. Tentunya masih banyak alternatif lain untuk pemindahan ibu kota negara, mengingat jumlah pulau di Indonesia lebih dari 17.000. Untuk pemilihan lokasi ibu kota perlu peraturan perundang-undangan. Undang-undang tata ruang saat ini sedang digodog di DPR, mudah-mudahan persyaratan ibu kota negara tidak terlewatkan atau terabaikan.(11)

Presiden pertama Republik Indonesia, Soekarno, yang pernah melontarkan ide memindahkan ibukota negara ke Kalimantan Tengah. Persisnya ke kota Palangkaraya, yang dibelah oleh sungai Kahayan. Mimpi Presiden Soekarno untuk memindahkan ibukota Negara itu dilontarkan pada tahun 1950-an. Saat itu, putra sang fajar tersebut sudah meramalkan bahwa Jakarta akan tumbuh tak terkendali. Pertimbangan Soekarno memilih Palangkaraya sebagai ibukota negara. Pertama, Kalimantan adalah pulau terbesar di Indonesia dan letaknya di tengah-tengah gugus pulau Indonesia. Kedua, menghilangkan sentralistik Jawa. Ketiga, pembangunan di Jakarta dan Jawa adalah konsep peninggalan Belanda, dan Soekarno ingin membangun sebuah ibu kota dengan konsepnya sendiri. Bukan peninggalan penjajah, tapi sesuatu yang orisinil. Satu hal lagi, seperti Jakarta yang punya Ciliwung, Palangkaraya juga punya sungai Kahayan. Soekarno ingin memadukan konsep transportasi sungai dan jalan raya, seperti di negara-negara lain. Ia juga ingin Kahayan secantik sungai-sungai di Eropa. Di mana warga dapat bersantai dan menikmati keindahan kota yang dialiri sungai. Untuk mewujudkan ide tersebut, Soekarno bekerjasama dengan Uni Soviet. Para insinyur dari Rusia pun didatangkan untuk membangun jalan raya di lahan gambut. Pembangunan ini berjalan dengan baik. Tapi seiiring dengan terpuruknya perekonomian Indonesia di awal 1960-an, pembangunan Palangkaraya terhambat. Puncaknya pasca 1965, Soekarno dilengserkan. Pada pemerintahan Presiden RI sekarang, Opsi pemindahan ibukota dari Jakarta sudah dikaji pemerintah sejak 3 Maret 2010, Staf Khusus Presiden Bidang Pembangunan Daerah dan Otonomi Daerah, Velix Wanggai, telah menyelenggarakan sebuah Strategic Policy Discussion bertajuk "Mengkaji Wacana Pemindahan Ibukota Negara: Strategi Membangun Berkeadilan".

Menurut Velix, Presiden selaku kepala negara melihat perlunya mengkaji wacana pemindahan Ibukota. Kondisi Jakarta sebagai sebuah ibu kota negara dirasakan semakin tidak nyaman. Beban fungsi pelayanan dan kelayakan Jakarta dirasakan semakin tidak optimal terutama akibat penyimpangan penataan ruang dan mempertimbangkan kemacetan lalu lintas, bencana banjir, dan kerawanan gempa. "Sehingga wacana kebijakan untuk memindahkan ibu kota negara dari Jakarta relevan dikemukakan.(1) Meski demikian ada beberapa hal yang masih pro dan kontra terhadap wacana tersebut, gubernur Kalimantan Tengah mengakui bahwa terdapat beberapa kekhawatiran dari beberapa tokoh masyarakat tentang wacana tersebut, terutama dampak perubahan sosiologis dari masyarakat Kalimantan Tengah yang hidup dalam karakteristik masyarakat sub-urban menjadi masyarakat ibu kota yang hidup dalam karakteristik masyarakat metropolitan. Adanya kekhawatiran megenai potensi terpinggirnya masyarakat lokal tersebut menuntut adanya perencanaan yang lebih serius dari pemerintah pusat untuk mengantisipasi 
dampak sosial apabila wacana pemindahan ibu kota negara benar-benar terwujud.(10)

Rekomendasi pemindahan Ibu Kota keluar Jawa justru berangkat dari keprihatinan akan daya dukung ekosistem dan bencana sosial di kota-kota besar di Jawa (seperti 1997-1998). Cadangan air bersih di Jawa saat ini hanya $20 \%$ dari kebutuhan. Tanah pertanian di Jawa tingkat kesuburannya lebih dari 3 kali lipat kesuburan lahan di luar Jawa. Perlahan tapi pasti, lahan pertanian itu terus diciutkan utk dikonversi menjadi kawasan industri, kota baru, proyek-proyek properti. Dengan model perkembangan seperti ini, kaum miskin desa sebagian besar hanya berpindah status menjadi kaum miskin kota.

Kalangan menengah bawah, yang satu atau dua level di atas kaum miskin kota, hidup dalam ketegangan dan stress yang semakin tinggi di luar ruang di kota-kota besar (Jakarta, Bandung dan sekitarnya). Hutan di Jawa pun makin menipis, sehingga menimbulkan ancaman banjir yang akan semakin mempersulit kehidupan para petani. Sebaliknya, di luar Jawa cadangan air bersih melimpah, sumber energi berlimpah. Mengapa kita tidak pindahkan sebagian kawasan industri ke luar Jawa, selain memindahkan juga ibu kota pemerintahan. Itulah alasan-alasan merekomendasikan pemindahan ibu kota ke luar Jawa.

\section{Kesimpulan}

Negara Kesatuan Republik Indonesia yang telah merdeka hampir genap 73 tahun, ibu kota negaranya (Jakarta) menempati bekas ibu kota penjajah (yang menjajah selama lebih dari tiga abad). Sebagai simbol kewibawaan negara dan jati diri bangsa saat ini dan masa depan kurang layak untuk dipertahankan, karena sebagai pemusatan kekuasaan dan pemusatan ekonomi banyak menimbulkan KKN, berpenduduk padat, tata ruang yang tidak tersusun rapi, kemacetan lalu lintas, berbagai konflik kepentingan, pencemaran, setiap tahun terlanda banjir, dan sanitasi lingkungan kurang memadai. Pemusatan kekuasaan dan kegiatan di ibu kota mempunyai risiko tinggi dalam kondisi kritis (perang), ibu kota menjadi sasaran untuk diserang.

Presiden pertama Republik Indonesia, Soekarno, pernah melontarkan ide memindahkan ibukota negara ke Kalimantan Tengah. Persisnya ke kota Palangkaraya, yang dibelah oleh sungai Kahayan. Pertimbangan Soekarno memilih Palangkaraya sebagai ibukota negara. Pertama, Kalimantan adalah pulau terbesar di Indonesia dan letaknya di tengah-tengah gugus pulau Indonesia. Kedua, menghilangkan sentralistik Jawa. Ketiga, pembangunan di Jakarta dan Jawa adalah konsep peninggalan Belanda. Kelebihan dari Kalimantan adalah lokasinya merupakan pusat dari wilayah Nusantara. Lahan masih sangat luas, sehingga dapat menyusun tata ruang ibu kota Negara yang sangat ideal. Kelemahannya adalah prasarana dan sarana belum memadai, sebagian besar harus membangun yang baru, berarti biaya mahal. Kelemahan lainnya adalah penyediaan air bersih, kebakaran hutan, banjir dan longsor merupakan bahaya yang perlu dijadikan dasar pertimbangan.

\section{Daftar Pustaka}

1. Amri AB. SBY Kaji Pindahkan Ibukota Sejak Maret [Online]. 2010. https://www.viva.co.id/berita/politik/168665istana-kaji-pindahkan-ibukota-sejak-maret [26 Apr. 2018].

2. Ayuningtyas RN, Rahayu S. Kajian Pemahaman Masyarakat Terhadap Banjir Di Kelurahan Ulujami, Jakarta. Teknik PWK (Perencanaan Wilayah Kota) 3: 351-358, 2014.

3. Baiquni M. Membangun Pusat-pusat di Pinggiran. Yogyakarta: Ideas, 2004.

4. Burger D.H. Sejarah Ekonomis Indonesia. Jakarta: Pradniyaparamita, 1962.

5. Ikhbal A. Perang-perang Paling Berpengaruh di Dunia. Yogyakarta: Jogja Bangkit Publisher, 2010.

6. Soekamto. Yogyakarta Ibukota Perjuangan. Yogyakarta: Salemba, 2017.

7. Surjomiharjdo. Ki Hajar Dewantara dan Taman Siswa dalam Sejarah Indonesia Moderen. Jakarta: Sinar Harapan, 1986.

8. Sutrisno. Sejarah Kalimantan. Yogyakarta: Indoliterasi, 2017.

9. Tjumano D. Ibukota Negara Pindah Kemana? [Online]. Jurnal Intelijen: 2017. http://jurnalintelijen.net/2017/05/16/ibukotanegara-pindah-kemana/ [26 Apr. 2018]. 
10. Toun NR. Analisis Kesiapan Pemerintah Provinsi Kalimantan Tengah dalam Wacana Pemindahan Ibu Kota Negara Republik Indonesia ke Kota Palangkaraya. Jurnal Academia Praja 1: 129-148, 2018.

11. Utama FR. Masalah Tata Ruang Harus Jadi Fokus Pemerintah [Online]. https://economy.okezone.com/: [date unknown].

https://economy.okezone.com/read/2016/11/0 3/470/1532118/masalah-tata-ruang-harusjadi-fokus-pemerintah [24 Apr. 2018]. 